\title{
The Preservation Strategy of Kethek Ogleng Pacitan in Millennial Era
}

\author{
Agoes Hendriyanto, Bakti Sutopo, Arif Mustofa
}

\begin{abstract}
Kethek Ogleng Pacitan is one of the magnum opus legacies in Indonesia. It is the performing arts living in the midst of the Pacitan society. In the same cases of other arts, Kethek Ogleng requires attention for its sustainability due to the marginalization of the present traditional art as well as the inclusion of arts originating from outside cultures which are considered more modern and advanced. Therefore, the preservation strategy must be contextualized with the current state of society. From this urgent need, however, the focused researches on such issues have not been significantly discussed. From this case, this research is aimed at revealing various strategies that can be utilized to preserve the Kethek Ogleng. To meet this aim, the qualitative descriptive, with the primary object Kethek Ogleng Pacitan Art, is employed. Further, the data collection uses a variety of methods including observation participants, interviews with Ogleng Kethek artists, and literature studies. It is thus worthwhile to be written that the preservation strategy of the Performing Arts in the millennial era can be both a short-term and long-term strategy. Then, the strategies are as follows; (1) Kethek Ogleng roadshow; (2) revitalization of the Wanoro Condro art studio; (3) art festivals; (4) citizens' celebrations; (5) extracurricular activities at various levels of educational institutions; (6) preserving the art as the intangible heritage so-called Warisan Budaya Tak Benda (WBTB); and (6) visualization as well as digitalization of Kethek Ogleng Pacitan.
\end{abstract}

\section{Index Terms: strategy, art, Kethek Ogleng, preservation.}

\section{INTRODUCTION}

Kethek Ogleng is the creation of the cipta (mind) and karsa (feeling and intention) of a Tokawi Pacitan resident named Sutiman. He created the art in 1962. At this moment, Kethek Ogleng needs conservation and advancement efforts to be favored with present and future generations. For this case, the preservation of the art can be undertaken by various parties both by the Pacitan Regency Government, artist-researchers, observers, and other parties. We note, however, from those parties, Pacitan Regency Government has the most important and a must role. It is as mandated in Law No. 5 of 2017 concerning the Advancement of Culture. It is stated that the Central Government and the Regional Government carry out "Cultural mainstreaming through education to achieve the goal of culture promotion". In this context, the Pacitan Government must be supported by other parties so that the preservation of Kethek Ogleng's art can wholly be systematic and successful.

Furthermore, by the same token, with the conditions of other people-based arts in the archipelago, Kethek Ogleng also has to sweat to be accepted by the supporting community. The legacy must compete with modern art that

Revised Manuscript Received on April 19, 2019.

Agoes Hendriyanto, Lecturer, STKIP PGRI Pacitan, EastJava, Indonesia.

Bakti Sutopo, Lecturer, STKIP PGRI Pacitan, EastJava, Indonesia.

Arif Mustofa, Lecturer, STKIP PGRI Pacitan, EastJava, Indonesia. reaches every social level. Kethek Ogleng is required to adapt to rapid and technology-based social change, by all means, it must also be able to position itself with the millennial generation mindset.

The millennial era is characterized by the virtual world development within various facilities to access unlimited foreign cultural arts. Consequently, it is considered more modern and to elevate the social status as inherent in the dancers and the connoisseurs of art. The young millennial generation, or so-called Kids Zaman Now in Indonesia, is infatuated with all modern things based on the worldview they follow. Hereupon, the existence of the modern culture including modern dance, little but sure, has been affecting the traditional art. The real impact is that traditional art will be abandoned by the millennial generation. In fact, traditional art will lose its artists. This phenomenon can happen to Kethek Ogleng if the art conservation will not immediately be carried out.

Important to realize that the efforts to preserve the Kethek Ogleng are not that easy in the case when these efforts face a major obstacle, that is the diminishing desire of the younger generation to learn the traditional art. Besides, there are still limited cultural and budgetary resources, although already mandated in Section 32 of the 1945 Constitution, that the Government advances Indonesian National Culture, and the cultural endeavor must lead to progress in adab (culture), unity without rejecting new material from foreign culture which can develop or enrich the nation's own culture and enhance the humanity of the Indonesian people.

Nevertheless, the efforts of observers of the Ogleng Pacitan Kethek Dance appear to have been very massive compared to before 2017. Since it was mandated in Law number 5 of 2017 concerning the Promotion of culture. It is aimed at developing noble values, enriching cultural diversity, strengthening national identity, educating the nation's life to preserve cultural heritage, and improving people's welfare. Even though there is no regional regulation related to the art and culture promotion or advancement at the Pacitan District level, but the Kethek Ogleng Pacitan manage to promote and preserve it.

One such effort undertaken by the Pacitan regency government is an annual agenda every October for each year. The performance of the Ogleng Kethek is held by art studio, community, government and the private sector as the strategies for its promotion and preservation. Sedyawati (1981, p. 52) argues that performance art in Indonesia departs from a situation where it grows in an ethnic, hereditary common ground or agreement on behavior that is

Published By:

Blue Eyes Intelligence Engineering

$\&$ Sciences Publication 
very large to determine the art rising.

With this history, the creation of the 1962 Kethek Ogleng dance by Sutiman, who at that time was still 18 years old, needed an uneasy struggle. Turning to sketch of the past, while taking a break after working in the fields, Mr. Sutiman Sutiman's intention was triggered to have seen the funny and interesting attractions. It motivated him to imitate the movement as a dance. Sutiman's reflection finally decided to see the movements of monkeys in Sriwedari zoo Surakarta in 1962 (Sutopo, et al, 2018, p. 20). Sutiman endeavor in producing the opus of Kethek Ogleng Dance must be preserved together. Henceforth, the intangible heritage can be appreciated by future generations.

The dance work extinction is one of some reasons, caused by the absence of successors. Those reasons include the obsolete dance, the fewer people pursuing art and culture, the inability to compete with modern culture. Therefore, there should be various efforts done by the government, the private sector, art studio, community, and non-governmental organization to preserve the Kethek Ogleng dance.

The challenges in preserving the culture, especially traditional arts, are increasingly arduous due to the current development and globalization. The current globalization has not only resulted in many changes which occur in people's real-life patterns but also reciprocally affect the culture of the community. Therefore, the preservation of the Pacitan Kethek Ogleng dance is required to the people inner values developed throughout remote areas in Pacitan, especially Tokawi Village, Nawangan Sub-district.

The main problem of this research is the various conservation strategies pursued by various parties for the sake of Pacitan's Kethek Ogleng dance existence. The preservation strategies include: (1) Kethek Ogleng roadshow; (2) revitalization of Condro Wanoro art studio; (3) art festival; (4) citizen celebration; (5) extracurricular activities at various levels of educational institutions; (5) protection of the Kethek Ogleng art by including it as the intangible heritage so-called Warisan Budaya Tak Benda (WBTB); and (6) visualization and digitalization of Kethek Ogleng Pacitan

This research generally aims at revealing the existence and the development of Pacitan Kethek Ogleng. Particularly, this study aims at uncovering various strategies pursued by various parties to preserve the art.

\section{LITERATURE REVIEW}

Kethek Ogleng is a performing art that includes dance. Dance is probably the best way to learn the rhythm and learn how to control our instinctive drive for movement (Georgios, 2016, p. 104). Dance is a spontaneous movement influenced by strong emotions (Rohkyatmo, 1986, p. 73). Besides, a motion is an important element of dance as a tool for conveying messages. Kethek Ogleng is an art that uses motion as a tool to convey its intention.

Kethek Ogleng art is originally created by Sutiman based on his experience to meet a monkey in his field (of unirrigated rice). This indicates that the birth process of the Kethek Ogleng art from a Sutiman is very simple and perhaps can be said to be coincidental. In conformity with the search of the informant and reinforced by Sukisno saw a group of wild monkeys play among the forest trees.

(2018, p. 6), the behavior of the monkey made Sutiman amazed and entertained. It turned out that the uniqueness of this primate behavior is imprinted deeply on Sutiman's heart. In his little heart, a supposition appears if he could move and act like a monkey he met; he would surely be able to entertain others. Strangely, the appearance of the monkey was only once which makes Sutiman not able to more deeply explore the funny movements of the animal he admired.

Being at a short glance, the Kethek Ogleng art is only an imitation of monkey movements. However, if each movement is observed; it is truly purposeful and meaningful like other artworks. These movements are actually closely related to human behavior in running their lives. In this context, the Kethek Ogleng art can be regarded as an interpretation medium as well as an understanding of various life problems. Surely, the interpretation and understanding of the Kethek Ogleng art movement are based on the worldview of the local society, namely the Javanese people.

Art is closely related to life. The art can be said to be a cultural product of human civilization; the face of a culture created by a group of people or a nation. Theoretically, art can be defined as cultural manifestations (priksa or pikiran dan rasa-thoughts and feelings; karsa-intentions or willingness; works or production of deed) of humans who have met aesthetic conditions (Ansari, 1986, p. 116). The art existence including dance must be preserved in the midst of community development because the art can be a visualization mediation of the local community values and at the same time, containing cultural values. Standing on the above mentioned coverage, the intangible heritage originates from local cultures in this Nusantara or archipelago, including: tradition, folklore and legend, mother tongue, oral history, creativity (dances, songs, drama shows), adaptability and the uniqueness of the local community (Galla, 2001, p. 12).

At its core, there should be strategies to preserve the art there. Performing arts include the sphere of public elements Pertaining to the stressing, Rubin (Bryson and Einsweiller 1988; Soeroso, Amiluhur, and Y. Sri Susilo, 2008, p.144) develops public sector strategies based on the time and the context of change. Those strategies are as follow: (1) "saga" (chronology) is a pattern of long-term actions to return values and objectives which begins to be threatened with loss due to the environmental changes, inaccuracies or management capacity. The idea is not to carry back the past but to regain lost quality and to respond to the new situations. Those types are: (a) restorative to returns lost quality through new policies and reorientation; (b) reformative to change government policies and procedures so that they can reflect appreciation in the past; (c) conservatory, a place for values preservation, institutions, and objectives threatened by changes; (2) "Quests" (standing for questions) that focus on a new future. The types of strategies are (a) new agenda for the long-term goals and objectives; (b) a big vision of the city, region or institution; 
(c) long-term alternative actions to anticipate a crisis or conflict.

These patterns employed by various parties to preserve the Kethek Ogleng Pacitan. To that end, it is expected that Ogleng Kethek can pass the challenges overtimes, remain to exist, and can always be appreciated by future generations.

\section{METHODS}

The field research was used to explore the subsurface of the problem. Further, the data collection method is participant observation, one of which is by getting involved in the Kethek Ogleng Dance at various places in Pacitan. Besides, the documentary techniques are also used by means of careful note-taking, picture, video activity, and the interview. Moreover, the qualitative data is taxonomically classified by researchers based on the criteria adapted from the problem statements. The research is carried out in Tokawi Village, Nawangan Sub-district, Pacitan Regency.

\section{RESULTS AND FINDING}

Strategies are careful plans for activities to achieve specific goals. The preservation of the Kethek Ogleng Pacitan is: first as a process, a scheme, to preserve the Kethek Ogleng Pacitan; second, the protection of Kethek Ogleng's art from extinction; third, the wise management of the Kethek Ogleng Pacitan to ensure the prolongation of regeneration while conserving and improving the quality of the art.

The most interesting finding, by looking intensity, notetaking, and participating preservation activity, was that Kethek Ogleng Pacitan can make a method called a conservation strategy. The challenge is not easy to protect the Kethek Ogleng Pacitan from extinction. The millennials, who do not feel how the night without electric light, do not want to study the art skills. It is easy to guide them from elementary to middle school at Condro Wanoro art studio; conversely, the difficult coordination begins after they have graduated from SMA (high school)/SMK (vocational school)/MA (Islamic high school). Therefore, there needs to be a breakthrough to build the Kethek Ogleng Pacitan socalled Conservation Strategy.

As has been noted, the Conservation Strategies of the Kethek Ogleng Art Pacitan in this Millennium Era are: 1) the roadshow, 2) the Condro Wanoro art studio, 3) the festival, 4) the citizen celebration, 5) the extracurricular in formal institutions, 5) the intangible heritage or Warisan Budaya Tak Benda (WBTB), 6) the visualization of Kethek Ogleng Pacitan. Further explanation of each strategy is explained below.

The Kethek Ogleng Roadshow was the result of a collaboration among Condro Wanoro Studio, the SocioCultural Development Community, the Pacitan Tourism Department with a performance form at the Tourist site in Pacitan. The goal was to introduce the Kethek Ogleng Pacitan as the Pacitan's art. On this point, the main purpose of promotion according to Kotler (2004: 122) is informing, influencing and persuading as well as reminding 'consumers about something both material or non-material products; in this case, the dance art performances.
The preservation of the Kethek Ogleng show were held at Kelayar Beach. It is combining unsure between the Pacitan beach beauty and the art as an attempt to integrate various aspects of art, culture, social and tourism. Being an annual agenda with the cost collaboration between the government, the private sector, and the arts actor, it will increase interest in Pacitan. Pacitan is not only rich in tourism object but also rich in art and culture.

The roadshow is as a venue for channeling dance talent for children after practicing in the art studio. The attempt to preserve and promote Kethek Ogleng Pacitan is by motivating art studio students to select dancers who have the ability to perform at one of the 2019 scheduled roadshows. The catched point or idea is that the roadshow requires extraordinary attention, especially regarding transportation from Condro Wanoro to the roadshow location due to its long distance.

The dancers who performed at the 12 scheduled places are conducted in turns so that no one dominated the performance. In addition, the same opportunity is provided for each dancer who joined the Condro Wanoro Studio to perform a certain place and time. Some Roadshow activities have several characteristics related to the performing dancers, unrepresentative places, duration of making up dancers, dancers still need an understanding related to cultural infaq (donation); to do otherwise is a need for senior personnel to think of honorarium issues.

In addition, before 2018 the Kethek Ogleng Pacitan was only scheduled to participate in the reog festival in Arjosari Village, Pacitan Regency instead of the roadshow agenda as a form of participation and promotion of Kethek Ogleng Pacitan dance to society in Arjosari Sub-district. Figure 2 shows the activities to participate in celebrating the annual agenda in Arjosari Sub-district, Reog Ponorogo festival.

The art studio is as one of the public institutions in a country that plays an important role in the development of cultural arts in an area. Sanggar, the art studio, or association is another element that can participate in art and culture preservation. The societal elements, relatively having attention and concern for the existence and continuity of the arts. Kethek Ogleng Condro Wanoro, in its conservation struggle, experienced obstacles especially the absence of operational costs from the Government or the private sector.

The independence of sanggar or the art studio, to be honest, is very reliable in order to preserve the Kethek Ogleng Pacitan. The studio operation is highly expected in the framework of its efforts to preserve Ogleng's artistry. However, the Condro Wanoro studio managed to make a valuable breakthrough, especially in the celebration of citizens, the road show, the success of the Ogleng team limitations.

Sanggar as a voluntary community organization in the context of developing the skills cannot tie dancers or those involved in the art of Kethek Ogleng. Moreover, players as the head of the household are expected to have every 
activity they do with appropriate compensation. If there is no budget, the roadshow or festival activities only present the attractions of Kethek Ogleng played by dancers who are still sitting in SD, SMP, and SMA/SMK. Before the existence of the government budget, the efforts of Condro Wanoro art studio to preserve and develop the Ogleng Pacitan have not been maximized. Condro Wanoro has no right to tie Kethek Ogleng players to appear in every performance.

Sukisno and several senior artists Kethek Ogleng carried out routine exercises every Sunday, 150 of mostly with young people in the Condro Wanoro (Sutopo, 2018, p. 38). However, for the routine training, there are only 30 students participated due to the condition of the studio that was still joining in the house of the Condro Wanoro Studio chairman. Nevertheless, the Condro Wanoro Studio has been recorded as a cultural art studio in Pacitan to have been budgeted for each year. There is a need for studio operational costs because all the training activities are free and no training fees. The goal is for many young people to participate in Condro Wanoro's training activities.

What important is, is not only about the routine training at the Condro Wanoro art studio, but also an event to yearly showcase the skills in dancing to the public. For the reason, Condro Wanoro, the society, and the government held the Kethek Ogleng Pacitan festival. The festival has been used as an annual agenda by the Pacitan Government through the Education Board Sub-Department of Culture since 2017. The Ogleng Kethek dance festival is held at the General Sudirman Monument in Pakisbaru Nawangan for each year, precisely in October. Because it has become an annual agenda, beside the innate energy from the Tokawi Village society; Pakisbaru Village, and Desa Pengung, are involuntary in charge of such costs. The budgeting is beared by the society, the government, and school institutions for the sake of preserving the Kethek Ogleng Pacitan.

The 2018 festival involved 150 dancers from Condro Wanoro who were supported by Nawangan 3 State Junior High School, Penggung Elementary School, Tokawi Elementary School, and Nawangan 1 State High School. The high enthusiasm of the Wanoro Condro students is visible with the aim of getting the Pacitan Regent award as a dancer in the Kethek Ogleng Festival 2018. For 2019, the agenda is expected to be more successful both the interest of society and the more entertaining Kethek Ogleng dance.

The hajatan-celebration-of society endeavors to preserve Kethek Ogleng dance. For professional dancers, it is as a means to get honorarium from those who invite the services. The amount of the fare depends on the location and demonstrated movement. The societal response to invite Kethek Ogleng is proof that this dance can compete with electone music and other modern events. Moreover, the existing potencies between a classic Kethek Ogleng dance and ballet dance are further empowered by the Condro Wanoro art studio.

The classical Kethek Ogleng dance usually consists of 1 to 2 so-called Ogleng dancers (male dancers of the Kethek Ogleng Pacitan). In the different way, the ballet with a mixture of blendrong (the term to start dancing activity) and kudangan (the content, message, story of the dance) will have a minimum of 15 minutes serving, along with minimally consisting of 10 players, those are 5 Ogleng dancers, 1 dancer as Panji Asmorobangum, 1 dancer as Condro Kirono, 1 dancer as Roro Tompe, and 2 dancers as Roro Tompe assistants. The performance at the hajatan events is highly dependent on the request and the funds' ability of the invitee.

Extracurricular as an attempt to preserve Kethek Ogleng Pacitan, one of them is extracurricular at both elementary school and junior high school around Tokawi Village, Nawangan Sub-district area. The restriction of the Kethek Ogleng coach has made it unable to meet the needs of each school. Finally, the extracurricular activities were held by the art and culture teachers themselves and at a certain time, Sanggar Condro Wanoro pays the school a visit to equalize the movements.

The government providesthe appreciation in the form of an award certificate for students participating in the Kethek Ogleng art preservation via extracurricular activities. Beside the Vocational School, the Elementary School students are also motivated by giving awards to those participating in the activities held by the Condro Wanoro art studio. the Regent award was infinite or invaluable value for the students. All participants received awards due to the contribution of the Kethek Oleng Pacitan.

The endeavor to preserve Kethek Ogleng Pacitan is by registering it as Indonesia's Intangible Cultural Heritage in 2019 through the Directorate of Heritage and Cultural Diplomacy. It is under the Ministry of Education and Culture. If the Kethek Ogleng gets legitimacy as Indonesia's Intangible Cultural Heritage in 2019, it will have a good impact on the Kethek Ogleng's art sustainability. Some privileges were obtained by Kethek Ogleng, especially important among them is getting support for preservation funds from the Republic of Indonesia government through the Ministry of Education and Culture. The legality of Kethek Ogleng art was safe, and also a vehicle for selfactualization for Kethek Ogleng artists. Then, it results in the internal and external motivation of the art preservation as well as its existence.

In addition, with the recognition of the intangible heritage called Warisan Budaya Tak Benda (WBTB), Kethek Ogleng will be balanced with the established art at the national level. Thus, the Ogleng Kethek art is no longer just a local pride of Pacitan but also national pride so that the art will be more strongly established in the future.

Visualization can be said as the disclosure of an idea or feeling by using forms, writings, maps, graphics and so on. Visuals on visual objects are the visual qualities possessed by the object in connection with the appearing value when the visual object has been interpreted or appreciated. The considerations regarding visual quality can be developed through two objects, namely: (1) understanding the work as a visual object, through the study of elements that construct the objects so that they can emerge the values of the visual quality; (2) understanding to the humans as subjects who observe or create works and have visual qualities, namely studying what is happening, the background, and the 
observing humans or creating works which have visual qualities, namely studying what is happening, the background, and the object-observing humans so that an emotional reaction appears in themselves (Masri, 2010, p.16).

Important to realize, the visualization is engineering in making images, diagrams or animations for the information display. In that case, visualization, in the form of images both abstract and real, has been known since the beginning of human civilization.

Lim, F. (2008) strengthened that humans are intelligent people who are very adaptive to their surroundings. Since ancient times, humans used tools to easify interaction with nature. In this different angle, the postmodern era has precisely left the modern era being structured, empirical, and mechanistic; and replaced them with an intelligence machine that produces virtual space. A new reality that the postmodern has produced a new species of a sign, a sign that is a sign itself, a sign in which the 'signified or a mental concept' is invalid.

In the scope of Kethek Ogleng art preservation, the visualization of various activities and the movement has been carried out. This strategy is able to attract the attention of the younger generation. Moreover, the results of visualization are virtualized through varied social media. The uploaded videos and images received a positive response from netizens so that those easify the Kethek Ogleng introduction.

Correspondingly, the upload of those various visual documents about the Kethek Ogleng has become a selfactivating digital footprint that will be long-lasting. Finally, the next generation can still trace and retrieve the pieces of information. The strategy of the virtualized visualization and digitalization turned out to have an impact on Kethek Ogleng. It is increasingly known by society and societal awareness of the art is feelable. Evidently, Kethek Ogleng won trust as a medium to introduce various cultures and attractions in Pacitan. In short, Kethek Ogleng is increasingly popular in society.

\section{CONCLUSION}

Returning to the question posed at the beginning of this research, it is now possible to state that the existence of Ogleng Kethek art absolutely needs to be preserved. Such preservation can be carried out collaboratively between parties by considering various factors including the inner and outer objectivity of the Kethek Ogleng art. In addition, the preservation of Kethek Ogleng can be achieved by both maintaining originality and on the other side also makes it acceptable to today's society. Furthermore, the conservation strategy can be divided into short-term and long-term conservation plans. As explained above, the preservation can be done by (1) Kethek Ogleng roadshow; (2) revitalization of the Wanoro Condro art studio; (3) art festivals; (4) citizens' celebrations; (5) extracurricular activities at various levels of educational institutions; (6) preserving the art as the intangible heritage so-called Warisan Budaya Tak Benda (WBTB); and (6) visualization as well as digitalization of Kethek Ogleng Pacitan. suggest applications and extensions.

\section{ACKNOWLEDGMENT.}

\section{REFERENCES}

1. Dharmawan Paluseri. D., et.al. (2019). Determination of Indonesia's Intangible Cultural Heritage in 2018. Directorate of Heritage and Cultural Diplomacy Directorate General of Culture Ministry of Education and Culture: Jakarta.

2. Fan Naa Na Muhammad, et.al.(2017). Extracurricular Learning of Dance with Local Wisdom Basis. Journal CATHARSIS, 6 (2), 108-114.

3. Galla, A. (2001). Guidebook for the Participation of Young People in Heritage. Conservation. Brisbane. Hall and Jones Advertising.

4. Goergios, Lykeas. (2018). The Transformation of Traditional Dance from Its First to Its Second Existence: The Effectiveness of Music-Movement Education and Creative Dance in The Preservation of Our Culture Heritage. Journal of Education and Training Studies, 6, (1), pp. 104-112.

5. Kotler. P.,\& Armstrong. G. (2004). Principles of Marketing. 10th ed. New Jersey: Prentice Hall.

6. Lim, F. (2008). Philosophy of Technology, Don Ihde About Human \& Tools. Yogyakarta: Kanisius

7. Masri, Andri. (2010). Visual Strategy (Playing with Formalistic and Semiotic to Produce Visual Quality in Design). Yogyakarta: Silk Mesh.

8. Rohkyatmo, Amir. (1986). Elementary Knowledge of Dance and Some Dance Problems. Jakarta: Depdiknas (Department of National Education).

9. Sedyawati, E. (1981). The growth of the Performing Arts. Jakarta: Sinar Harapan.

10. Soeroso, Amiluhur, \&Y. Sri Susilo.( 2008). Local Culture Conservation Strategy. Journal of Theory and Applied Management,1( 2), 144-161.

11. Sukisno. (2018). The Art of Kethek Ogleng Pacitan: Ancestral Heritage and All Its Dimensions. Yogyakarta: Azyan Mitra Media.

12. Sutopo, Bakti, dan Agoes Hendriyanto \& Arif Mustofa (2018). Kethek Ogleng The Monumental and Original Art of Pacitan Land. Yogyakarta: Ladang Kata.

13. Law of the Republic of Indonesia Number 5 of 2017 concerning Promotion of Culture. Retrieved from https://kebudayaan.kemdikbud.go.id. On 9 April 2019 11.30 PM.

\section{AUTHORS PROFILE}

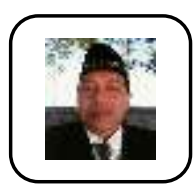

Agoes Hendriyanto was born in Pacitan on January $19^{\text {th }} 1971$. He is STKIP PGRI Pacitan Lecturer.

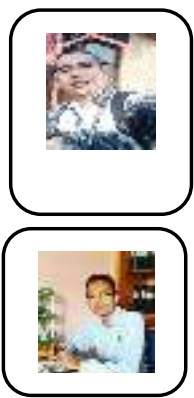

Bakti Sutopo was born in Pacitan on September $8^{\text {th }}$ 1980. He is STKIP PGRI Pacitan Lecturer.

Arif Mustofa was born in Pacitan on November $29^{\text {th }}$ 1979. He is STKIP PGRI Pacitan Lecturer. 